\title{
PENGARUH MODEL PEMBELAJARAN MURDER (MOOD, UNDERSTAND, RECALL, DEGEST, EXPEND, REVIEW) TERHADAP HASIL BELAJAR SISWA
}

\author{
Syafrizal $^{1^{*}}$, Muliani ${ }^{1}$, Novia Miranti ${ }^{2}$ \\ Dosen $^{1}$, Mahasiswa ${ }^{2}$ Program Studi Pendidikan Fisika, Universitas Malikussaleh \\ *e-mail: muliani@unimal.ac.id
}

\begin{abstract}
Abstrak: Penelitian ini bertujuan untuk mengetahui hasil belajar siswa dengan menggunakan model pembelajaran MURDER pada materi gelombang. Jenis penelitian ini adalah quasi eksperimen dengan menggunakan rancangan Nonequivalent Control Group Design. Populasi penelitian ini adalah seluruh siswa kelas VIII SMP Negeri 2 Dewantara. Sampel dipilih dengan teknik Purposive Sampling sehingga kelas VIIIA sebagai kelas kontrol dengan jumlah 31 siswa dan kelas VIIIB sebagai kelas eksperimen dengan jumlah 30 siswa. Berdasarkan analisis data, hasil belajar siswa kelas ekperimen untuk soal pilihan ganda diperoleh nilai rata-rata posttest sebesar 72,00 dan kelas kontrol sebesar 59,61. Nilai uji independent sample t test pada soal pilihan ganda diperoleh nilai signifikan 2-tailed sebesar 0,003 $<0,05$ dan soal essay diperoleh nilai signifikan 2-tailed sebesar $0,000<0,05$. Hal ini dapat disimpulkan bahwa terdapat pengaruh model pembelajaran MURDER yang signifikan terhadap hasil belajar siswa di SMP Negeri 2 Dewantara.
\end{abstract}

\section{Kaca Kunci: Model Pembelajaran MURDER, Hasil Belajar Siswa, Gelombang}

\section{INFLUENCE OF THE STUDENT'S LEARNING MURDER MODELS}

\begin{abstract}
The study is intended to indentify the result of student's learning using the MURDER model on wave subject. This type of research is an experimental quasi using the nonequivalent control group design. The research population is all VIII SMP Negeri 2 Dewantara. Samples were selected by impressive sampling technique so that grade VIIIA as a control class with the number of 31 students and class VIIIB as an experimental class of 30 students. According to data analysis, the result of studying experimental students on the matter of multiple choice were obtained total of 72.00 posttest marks and control class of 59,61. The independent test value of sample $t$ test on the question of multiple choice is attained a significant 2 -tailed value of $0.003<0.05$ and essay value of $0.000<0.05$. It may be concluded that there is a significant MURDER learning model impact on students learning in SMP Negeri 2 Dewantara.
\end{abstract}

\section{Keyword: MURDER Model, Student Studying, Wave}

\section{PENDAHULUAN}

Pendidikan berasal dari kata didik, anak di didik bukan hanya di sekolah tetapi dirumah pun orang tua juga ikut berperan dalam mendidiknya. Guru selain bertugas untuk mengajar juga dituntut untuk mampu mendidik siswa menjadi pribadi yang memiliki akhlak mulia. Oleh karenanya selain peran guru, peran orang tua pun sangat diperlukan dalam mengawasi baik itu dalam hal belajar ataupun bermain. Karena hal tersebut sangat mempengaruhi sikap perilaku dan hasil belajar siswa apalagi ilmu pengetahuan dan teknologi sekarang semakin berkembang.

Hasil belajar adalah terjadinya perubahan tingkah laku pada diri seseorang yang dapat diamati dan diukur dalam bentuk pengetahuan, sikap dan keterampilan. Perubahan tersebut 
dapat diartikan sebagai terjadinya peningkatan dan pengembangan yang lebih baik sebelumnya yang tidak tahu menjadi tahu (Hamalik, 2008). Faktor-faktor yang mempengaruhi hasil belajar dapat digolongkan menjadi 2 yaitu faktor internal dan faktor eksternal. Faktor internal adalah faktor yang berasal dari dalam diri individu seperti faktor jasmaniah, faktor psikologis dan faktor kelelahan. Faktor eksternal adalah faktor yang ada di luar individu seperti faktor keluarga, faktor sekolah dan faktor masyarakat (Slameto, 2010).

Berdasarkan observasi awal pada sekolah SMP Negeri 2 Dewantara, hasil belajar siswa tergolong belum maksimal dilihat dari hasil ulangan sehari-hari dan latihan-latihan soal yang diberikan oleh guru, masih banyak siswa yang tidak bisa menjawab soal-soal tersebut. Penggunaan model dan media pembelajaran yang dilakukan oleh guru dikelas kurang bervariasi sehingga membuat siswa merasa bosan dalam mengikuti pelajaran. Dimana hasil belajar yang baik salah satunya didukung oleh penggunaan model atau metode yang sesuai dengan materi yang disampaikan, kondisi siswa dan sarana yang tersedia (Haris \& Fandi, 2016).

Model pembelajaran MURDER terdiri atas mood, understand, recall, degest, expend, review, pembelajaran ini menciptakan suasana belajar yang menyenangkan dan lebih menarik, sehingga meningkatkan pencapaian hasil belajar siswa pada proses pembelajaran (Ely \& J.A., 2014). Dengan model pembelajaran MURDER siswa lebih mudah memahami suatu materi karena mereka mendapatkan penjelasan dengan gaya bahasa mereka sendiri. Guru juga dapat lebih berkonsentrasi dalam mendengarkan jawaban dan mengamati reaksi siswa. Dengan demikian, guru dapat mengambil tindakan yang tepat untuk membantu siswa yang mengalami kesulitan (Juniantari, 2011). Adapun langkah-langkah model pembelajaran MURDER yaitu (1) Mood (suasana hati), proses pembelajaran yang diawali dengan membuat suasana hati siswa menjadi lebih bersemangat untuk memulai pembelajaran sehingga tercipta kegiatan pembelajaran yang kondusif (Haris \& Fandi, 2016). (2) Understand (pemahaman), siswa didorong untuk membaca dan memahami materi yang akan disajikan kemudian diminta menandai hal-hal yang tidak dipahami seperti siswa diminta untuk membaca buku pokok/bahan ajar tentang materi yang akan dipelajari kemudian menandai materi-materi yang belum dimengerti (Musawwir, 2018). (3) Recall (pengulangan), menyusun kembali informasi yang didapat dan menjelaskan materi dengan gaya bahasa sendiri (Haris \& Fandi, 2016). (4) Degest (penelaahan), siswa dituntut untuk mendeskripsikan apa yang telah dipahami. Keberhasilan suatu proses pengajaran diukur sejauh mana siswa dapat menguasai materi pembelajaran yang disampaikan guru. Agar siswa dapat menguasai suatu materi, maka tidak cukup hanya menggunakan satu sumber saja, namun juga dituntut untuk mencari sumber lain yang tidak disediakan oleh guru (Musawwir, 2018). (5) Expend (pengembangan), siswa dituntut untuk mengembangkan materi yang telah dikuasai karena dengan pengembangan siswa akan mendapatkan informasi yang lebih banyak. Dari informasi yang telah di dapat, siswa diharapkan dapat mengembangkan konsep dan juga dapat mengaitkan dengan situasi lain berdasarkan konsep dasar pada suatu materi tertentu (Musawwir, 2018). (6) Review (pelajari kembali), siswa diminta untuk mempelajari kembali secara keseluruhan materi yang telah dipelajari. Selanjutnya siswa secara individu membuat kesimpulan tanpa melihat bahan ajar yang digunakan dalam proses pembelajaran (Musawwir, 2018). Kelebihan model pembelajaran MURDER antara lain dapat melatih pendengaran, ketelitian/kecermatan, setiap siswa mendapat peran dan melatih mengungkapkan kesalahan orang lain dengan lisan. Namun kekurangan model ini yaitu hanya untuk mata pelajaran tertentu dan hanya dilakukan dua orang (tidak melibatkan seluruh kelas sehingga koreksi hanya sebatas pada dua orang tersebut. (Miftahul'Ala, 2011). 
Beberapa penelitian menunjukkan bahwa menggunakan model pembelajaran MURDER memiliki hasil belajar yang lebih baik. Berdasarkan penelitian Ely Agus Setiyowati dan J. A Pramukantaro (2014), Rata-rata hasil belajar siswa kelas eksperimen dengan menggunakan model pembelajaran MURDER adalah sebesar 88,9 dan kelas kontrol menggunakan model pembelajaran konvensional adalah sebesar 82,7. Sehingga dapat disimpulkan bahwa hasil belajar siswa menggunakan model pembelajaran MURDER lebih baik dibandingkan dengan model pembelajaran konvensional. Kemudian berdasarkan hasil penelitian yang dilakukan oleh K. Darmika, dkk (2014), menyatakan bahwa terdapat perbedaan motivasi dan prestasi belajar antara kelompok siswa yang belajar menggunakan model pembelajaran MURDER dengan model pembelajaran konvensional. Motivasi dan prestasi belajar siswa yang belajar dengan model pembelajaran MURDER lebih baik daripada model pembelajaran konvensional, Hal ini dibuktikan oleh nilai rata-rata prestasi belajar siswa kelas eksperimen diperoleh sebesar 72,58 dan kelas kontrol sebesar 64,98. Sedangkan nilai rata-rata motivasi kelas eksperimen sebesar 74,04 dan kelas kontrol sebesar 68,69. Selanjutnya berdasarkan hasil penelitian yang dilakukan oleh Isran dan Hidayati (2016) diperoleh $t_{\text {hitung }}=$ 2,500 dan $\mathrm{p}=0,015$, karena $\mathrm{p}<0,05$ maka hipotesis yang diajukan diterima dan signifikan, Sehingga dapat disimpulkan bahwa ada perbedaan yang signifikan prestasi belajar fisika antara pembelajaran menggunakan model pembelajaran MURDER dengan model konvensional. Dan berdasarkan hasil penelitian yang dilakukan oleh Haris Munandar dan Fandi Ahmad (2016) menyatakan bahwa penerapan model pembelajaran MURDER dapat meningkatkan hasil belajar biologi siswa kelas XI IPA 5. Hal ini dibuktikan dengan meningkatnya nilai rata-rata yang diperoleh siklus I dan siklus II. Nilai rata-rata pada siklus I adalah 73 berada pada kategori sedang dan pada siklus II meningkat menjadi 80 berada pada kategori tinggi.

\section{METODE}

Jenis penelitian yang digunakan dalam penelitian adalah quasi eksperimen. Quasi eksperimen adalah desain yang digunakan karena pada kenyataannya sulit mendapatkan kelompok kontrol yang digunakan untuk penelitian (Sugiono, 2014). Desain yang digunakan yaitu Nonequivalent control group design dimana kelompok eksperimen maupun kelompok kontrol tidak dipilih secara random (Sugiyono, 2019). Penelitian dilaksanakan di SMP Negeri 2 Dewantara kelas VIII. Adapun populasi dalam penelitian ini adalah seluruh siswa kelas VIII di SMP Negeri 2 Dewantara yang berjumlah 61 siswa. Sampel penelitian diambil menggunakan teknik sampling purposive. Sehingga sampel yang diambil yaitu VIIIA sebagai kelas kontrol dengan jumlah siswanya sebanyak 31 siswa yang terdiri dari 17 laki-laki dan 14 perempuan. Sedangkan kelas VIIIB sebagai kelas eksperimen dengan jumlah siswanya 30 siswa yang terdiri dari 18 laki-laki dan 12 perempuan.

Teknik pengumpulan data dilakukan dengan memberikan lembar tes (pretest dan posttest) dan angket. Lembar tes digunakan untuk melihat hasil pretest dan posttest siswa, sedangkan angket untuk melihat respon siswa setelah dilakukan percobaan. Tes berjumlah 30 soal yang terdiri dari 25 soal pilihan ganda dan 5 soal essay, sedangkan angket berjumlah 25 pernyataan. Uji coba instrument yang digunakan dalam penelitian ini adalah uji validitas, uji reliabilitas, uji tingkat kesukaran dan daya pembeda. Sebelum dilakukan uji hipotesis maka data penelitian harus memenuhi syarat analisis yang meliputi uji normalitas dan uji homogenitas. Uji normalitas data menggunakan Shapiro-Wilk dan uji homogenitas menggunakan statistik Levene. Selanjutnya data dianalisis secara deskriptif dan menggunakan aplikasi SPSS 18. 


\section{HASIL DAN PEMBAHASAN}

\section{Hasil}

Hasil analisis hasil belajar siswa pada soal pilihan ganda dan soal essay adalah sebagai berikut:

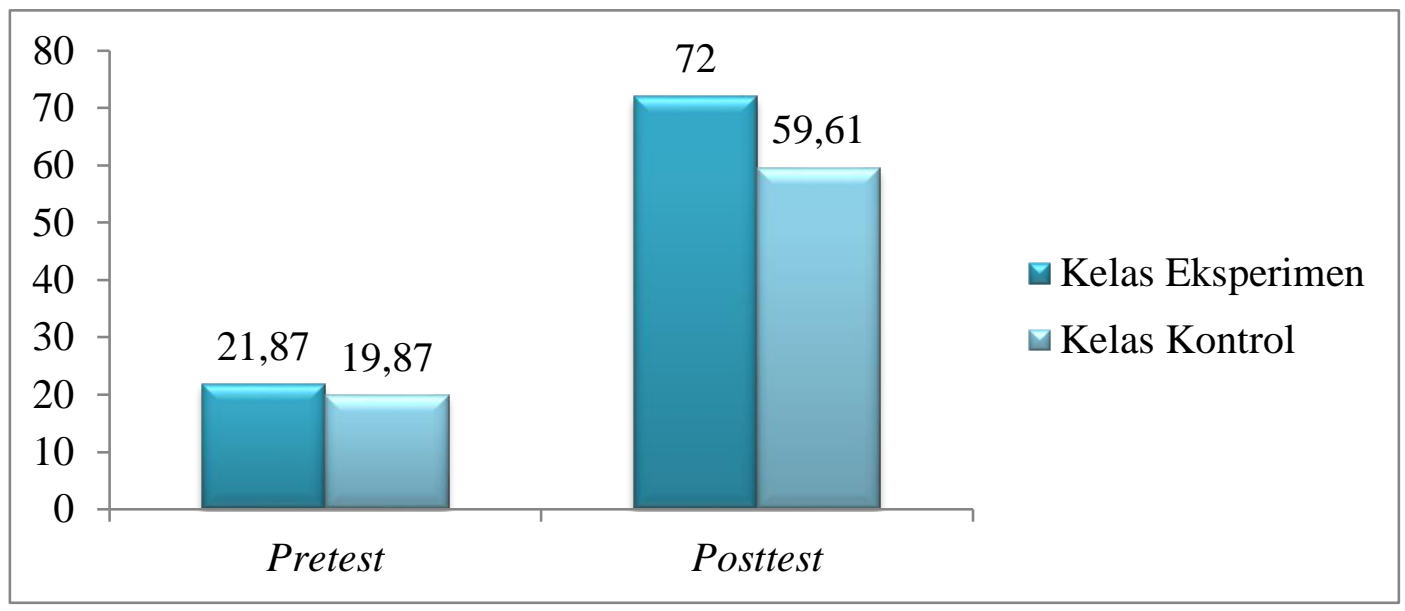

Diagram.1 Nilai Rata-rata Hasil Belajar Kognitif Siswa Soal Pilihan Ganda

Berdasarkan Diagram.1 nilai rata-rata hasil belajar siswa pretest dikelas eksperimen sebesar 21,87 lebih tinggi dibandingkan dengan kelas kontrol sebesar 19,87. Nilai rata-rata hasil belajar siswa posttest dikelas eksperimen sebesar 72 lebih tinggi dibandingkan kelas kontrol sebesar 59,61.

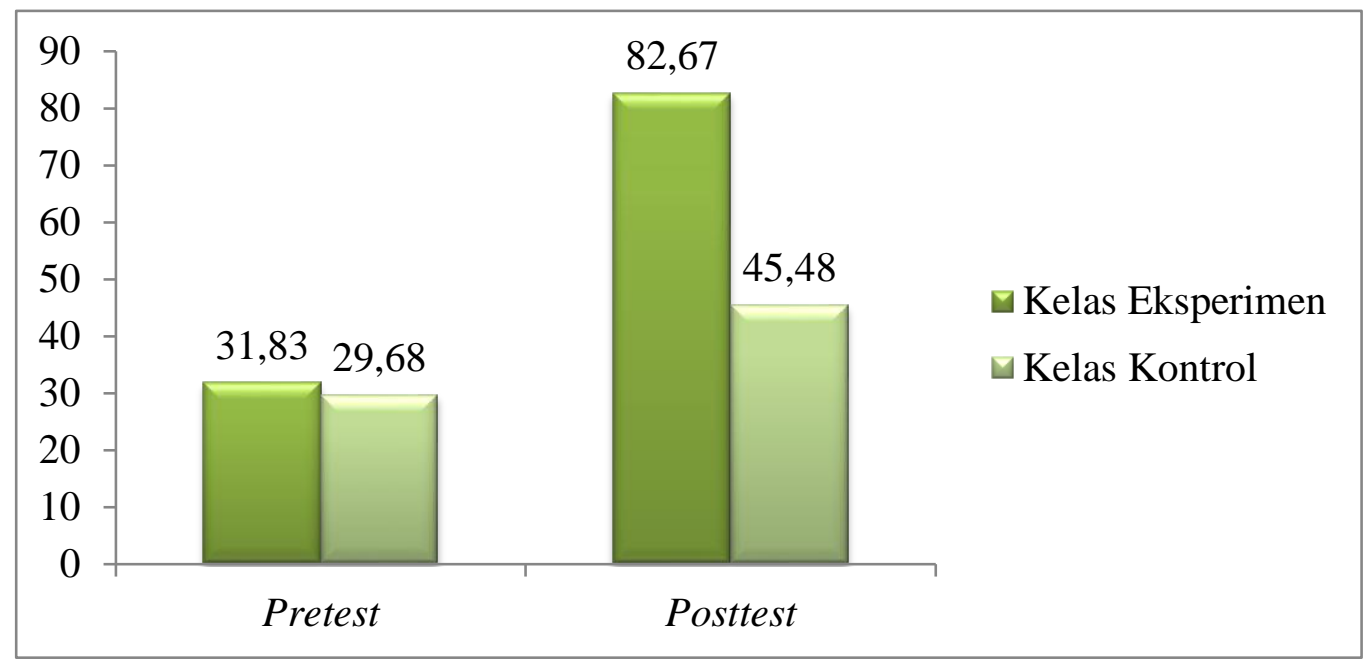

Diagram. 2 Nilai rata-rata hasil belajar kognitif siswa soal essay

Berdasarkan Diagram. 2 nilai rata-rata hasil belajar siswa pretest dikelas eksperimen sebesar 31,83 lebih tinggi dibandingkan dengan kelas kontrol sebesar 29,68. Nilai rata-rata hasil belajar siswa posttest dikelas eksperimen sebesar 83,67 lebih tinggi dibandingkan kelas kontrol sebesar 45,48. 
Tabel 1. Data Deskriptif Respon Siswa

\begin{tabular}{|c|c|c|c|c|c|c|}
\hline & $\begin{array}{c}\text { Jumlah } \\
\text { Siswa }\end{array}$ & Minimum & Maksimum & $\begin{array}{c}\text { Nilai } \\
\text { Rata-rata }\end{array}$ & $\begin{array}{l}\text { Standar } \\
\text { Deviasi }\end{array}$ & Var \\
\hline $\begin{array}{l}\text { Kelas } \\
\text { Eksperimen }\end{array}$ & 30 & 65 & 86 & 74,267 & 5,336 & \\
\hline Kelas Kontrol & 31 & 57 & 78 & 69,903 & 5,412 & 29 \\
\hline \multicolumn{7}{|c|}{ Tabel 2. Uji Normalitas } \\
\hline & \multicolumn{2}{|c|}{ Soal Pilihan Ganda } & \multicolumn{2}{|c|}{ Soal Essay } & & \\
\hline & Pretest & Posttest & Pretest & Posttest & Keterangan & \\
\hline $\begin{array}{l}\text { Kelas } \\
\text { Eksperimen }\end{array}$ & 0,168 & 0,090 & 0,202 & 0,095 & Normal & \\
\hline Kelas Kontrol & 0,161 & 0,075 & 0,239 & 0,060 & Normal & \\
\hline
\end{tabular}

Tabel 3. Uji Homogenitas

\begin{tabular}{ccccc}
\hline \multicolumn{2}{c}{ Soal Pilihan Ganda } & \multicolumn{3}{c}{ Soal Essay } \\
\hline Pretest & Posttest & Pretest & Posttest & Keterangan \\
\hline 0,863 & 0,086 & 0,294 & 0,056 & Homogen \\
\hline
\end{tabular}

Tabel 4. Uji Independent Sample T Test

\begin{tabular}{ccccc}
\hline \multicolumn{2}{c}{ Soal Pilihan Ganda } & \multicolumn{3}{c}{ Soal Essay } \\
\hline Pretest & Posttest & Pretest & Posttest & Keterangan \\
\hline 0,470 & 0,003 & 0,540 & 0,000 & Signifikan \\
\hline
\end{tabular}

Berdasarkan tabel 1 Nilai rata-rata siswa kelas eksperimen sebesar 74,267, sedangkan kelas kontrol sebesar 69,903. Dari nilai rata-rata kedua kelas maka dapat disimpulkan bahwa data respon siswa dikategorikan baik.

Pada tabel 2, diperoleh uji normalitas pretest untuk soal pilihan ganda pada kelas eksperimen yaitu 0,168 dan kelas kontrol yaitu 0,161 . Uji normalitas untuk pretest soal essay pada kelas eksperimen yaitu 0,202 dan kelas kontrol yaitu 0,239. Uji normalitas posttest untuk soal pilihan ganda pada kelas eksperimen yaitu 0,090 sedangkan kelas kontrol sebesar 0,075. Uji normalitas posttest untuk soal essay kelas eksperimen yaitu 0,095 dan kelas kontrol yaitu 0,060. Dikarenakan nilai signifikan > 0,05 maka dapat disimpulkan bahwa data berdistribusi normal.

Pada tabel 3, diperoleh uji homogenitas pretest untuk soal pilihan ganda pada kelas eksperimen dan kelas kontrol yaitu 0,863 dan uji homogenitas pretest untuk soal essay yaitu 0,294 . Kemudian uji homogenitas posttest untuk soal pilihan ganda yaitu 0,086 dan uji homogenitas posttest untuk soal essay yaitu 0,056. Dikarenakan signifikan >0,05 maka dapat disimpulkan bahwa data memiliki varians yang sama atau homogen.

Pada tabel 4, uji Independent Sample T Test pretest untuk soal pilihan ganda diperoleh nilai sig (2-tailed) 0,470 > 0,05 dan uji Independent Sample T Test pretest untuk soal essay diperoleh nilai sig (2-tailed) 0,540 >0,05. Hal ini menunjukkan bahwa tidak terdapat perbedaan yang signifikan antara hasil belajar kelas eksperimen dan kelas kontrol. Selanjutnya uji Independent Sample T Test posttest untuk soal pilihan ganda diperoleh nilai sig. (2-tailed) adalah 0,003 < 0,05 dan uji Independent Sample T Test posttest untuk soal essay diperoleh sig. (2-tailed) adalah $0,000<0,05$. Hal ini dapat disimpulkan bahwa terdapat pengaruh model 
pembelajaran MURDER (Mood, Understand, Recall, Degesr, Expend, Review) terhadap hasil belajar siswa pada materi gelombang.

\section{Pembahasan}

Berdasarkan hasil analisis data yang telah dilakukan untuk soal pilihan ganda diperoleh nilai rata-rata posttest kelas eksperimen sebesar 72,00 dan kelas kontrol sebesar 59,61 sementara hasil rata-rata posttest untuk soal essay pada kelas eksperimen yaitu 82,67 dan kelas kontrol yaitu 45,48. Berdasarkan nilai tersebut dapat dikatakan bahwa hasil belajar siswa kelas eksperimen telah mencapai nilai KKM sedangkan nilai kelas kontrol belum mencapai KKM, KKM yang ditetapkan senilai 70. Hasil ini menunjukkan bahwa adanya perubahan secara signifikan terhadap hasil belajar siswa yang menggunakan model pembelajaran MURDER. Hasil ini didukung oleh penelitian yang dilakukan oleh Abdul Musawwir (2018) dengan judul pengaruh model pembelajaran kolaboratif MURDER terhadap pemahaman konsep matematis siswa MTs, yang menyatakan bahwa model pembelajaran kolaboratif MURDER memberikan pengaruh baik yang besar terhadap kemampuan pemahaman konsep siswa.

Berdasarkan hasil data yang diperoleh terdapat pengaruh model pembelajaran MURDER (Mood, Understand, Recall, Degest, Expend, Review) terhadap hasil belajar siswa pada materi gelombang. Hal ini dapat dilihat dari hasil uji hipotesis yang menggunakan uji independent sample t test. Hal ini dibuktikan pada soal pilihan ganda diperoleh sig. (2-tailed) yaitu $0,003<$ 0,05 yang menunjukkan bahwa $\mathrm{H}_{\mathrm{o}}$ ditolak. Sementara hasil uji t pada soal essay diperoleh sig. (2-tailed) $0,000<0,05$. Hasil ini didukung oleh penelitian yang dilakukan oleh Nurhidayah (2018) dengan judul implementasi strategi belajar kooperatif MURDER terhadap pemahaman konsep fisika peserta didik kelas XI IPA SMAN 6 wajo kabupaten wajo yang menyatakan bahwa terdapat perbedaan yang signifikan antara pemahaman konsep fisika siswa yang diajar dan siswa yang tidak diajar dengan strategi belajar kooperatif MURDER.

\section{PENUTUP}

Kesimpulan dari penelitian ini adalah terdapat pengaruh model pembelajaran MURDER terhadap hasil belajar siswa pada materi gelombang di SMP Negeri 2 Dewantara. Hal ini dapat dilihat dari hasil nilai rata-rata posttest siswa kelas eksperimen yaitu 72,00 dan kelas kontrol yaitu 59,61 untuk soal pilihan ganda. Dan hasil nilai rata-rata posttest untuk soal essay pada kelas eksperimen yaitu 82,67 dan kelas kontrol yaitu 45,48. Maka dapat disimpulkan bahwa model pembelajaran MURDER berpengaruh secara signifikan terhadap hasil belajar siswa. Hal ini dibuktikan dengan uji Independent Sample T Test untuk soal pilihan ganda diperoleh sig. (2-tailed) yaitu 0,003 $<0,05$ dan soal essay diperoleh sig. (2-tailed) yaitu 0,000<0,05. Kemudian hasil respon siswa diperoleh pada kelas eksperimen sebesar 74,267\% dan kelas kontrol sebesar 69,903\%. Maka respon siswa dikategorikan baik.

\section{DAFTAR PUSTAKA}

'Ala, M. (2011). Quantum Teaching. Yogyakarta: Diva pres.

Darmika, K., Suma, K., \& Suastra, I. (2014). Pengaruh Model Pembelajaran Kooperatif MURDER Terhadap Motivasi Belajar dan Prestasi Belajar IPA Siswa SMP. e-Journal Program Pascasarjana Universitas Pendidikan Ganesha. Volume 4. 
Ely, S.A., \& J.A.,P. (2014). Model Pembelajaran Kooperatif MURDER Untuk Meningkatkan Hasil Belajar Siswa Pada Kompetensi Inti Teknik Elektronika Di SMK Negeri 1 Nganjuk. Jurnal Pendidikan Teknik Elektro, Volume 03, Nomor 01, 155-162.

Hamalik, Oemar. (2008). Teknik Pengukuran dan Evaluasi Pendidikan. Bandung: Mandar Maju.

Haris, M., \& Fandi, A. (2016). Penerapan Model Pembelajaran MURDER Untuk Meningkatkan Hasil Belajar Biologi Siswa Kelas XI IPA SMA Negeri 12 Makassar. Jurnal Bionature, Volume 17, Nomor 2, 76-80.

Isran, \& Hidayati. (2016). Pengaruh Model Pembelajaran MURDER (Mood, Understand, Recall, Digest, Expend, Review) Terhadap Prestasi Belajar Fisika. Jurnal Ilmiah Pendidikan Fisika-COMPTON, Volume 3, Nomor 1, 71-77.

Juniantari, M. (2011). Pengembangan Perangkat Pembelajaran Matematika Realistik dengan Seting Model Kooperatif MURDER Bagi Siswa SMP Kelas VII. Singaraja: Pascasarjana.

Musawwir, A. (2018). Pengaruh Model Pembelajaran Kolaboratif MURDER Terhadap Pemahaman Konsep Matematis Siswa MTs. Skripsi. Banda Aceh: Universitas Islam Negeri Ar-Raniry Darussalam.

Nurhidayah. (2018). Implementasi Strategi Belajar Kooperatif MURDER Terhadap Pemahaman Konsep Fisika Peserta Didik Kelas XI IPA SMAN 6 Wajo Kabupaten Wajo. Skripsi. Makassar: UIN Alauddin Makassar.

Slameto. (2010). Belajar dan Faktor-faktor yang Mempengaruhinya. Jakarta: PT. Rineka Cipta.

Sugiyono. (2014). Metode Penelitian Pendidikan. Bandung: Alfabeta.

Sugiyono. (2019). Metode Penelitian Kuantitatif, Kualitatif, dan R\&D. Bandung: Alfabeta. 